\title{
Tourism Demand in Malaysia: A cross-sectional pool time-series analysis
}

\author{
Mohd Hafiz Mohd Hanafiah and Mohd Fauzi Mohd Harun
}

\begin{abstract}
This paper estimates tourism demand in Malaysia based on the key economic factors like income, price, exchange rate, consumer price index, distance, population and economic crisis using a modified Gravity model. The movement, pattern and changes of international tourist arrivals are also examined. A cross-sectional pool time-series of tourist arrivals from Australia, Hong Kong, Indonesia, United Kingdom, Thailand, Taiwan and China through using modified Gravity Model was applied. Log-linear equation indicates that the tourism demand is highly correlated with Gross National Income (GNI) of the countries which showing the impact on the standard of living. On the other hand, tourism demand negatively correlated with Exchange Rate (ER) as tourist from higher purchasing power prefers to visit Malaysia. Consumer Price Index (CPI) or inflation rate reduce number of tourist to travel. The increasing number of tourist arrivals was influenced by population growth and distance may reduce tourism demand. Economic crisis negatively affected the tourism demand from the ASEAN countries but positively correlated with the western and other continents. This study clearly indicates that despite of regional economic crisis Malaysian government can still rely on tourism industry as a means of sustaining the economy through international tourists.
\end{abstract}

Index Terms - estimating, tourism, demand, Malaysia

\section{INTRODUCTION}

During the last several decades' tourism has emerged as one of the major industries in the world economy. Tourism revenues have grown to the third largest industry after oil and automobiles. This sector constitutes nearly $10 \%$ of the world gross income, $8 \%$ of world exports and up to $35 \%$ of world trade in services. The number of tourists' journeys increased from 25 million in 1950 to 700 million in 2003 , and is predicted to reach 1.6 billion in 2020 (WTTC, 2006). This implies that average annual growth rate of tourism sector at $3.5 \%$, while the growth rate of heavy industry is $3 \%$ (WTTC, 2006). International tourism has becoming a major foreign exchange earner for many low-income countries and small islands, and it is a principal export for $83 \%$ of developing countries (WTO, 2002). Many countries attempt to develop tourism sector and increase the number of incoming visitors because of several reasons: international tourists bring foreign currency to the host country; tourism sector is much more merciful toward environment than many industries producing goods; and growth in tourism industry accelerates other related industries (retail, entertainment and transportation).

As with other countries in the world, tourism industry can be claimed as an important sector for the Malaysian economy. It has been identified as the second largest foreign exchange earning sector and helped to strengthen the economy. The number of visitors from Western continent, North America and particularly the Gulf region has raised phenomenally in the recent year led the Tourism Malaysia's to woo more visitors from these continent and region. As such, 147,646 tourists from Gulf region visited Malaysia during 2005 which represent 17.1 per cent increased compared to 29,606 tourists in 2004. Worth mentioning that the increasing number of tourists to this country has come a long way after the setback experienced of the Asian Financial Crisis of 1997/1998 when tourist arrivals reached to a new record of 16.4 million in 2005 from 5.5 million before the economic turmoil (Tourism Malaysia, 2006). The economic crisis in ASEAN region positively created tourism demand from those regions and this in turn spurred the local industry. The higher exchange rate of foreign currencies against Malaysia Ringgit has stimulated tourists from those mentioned regions to visit Malaysia. This is proven with the impressive tourists receipts of USD 8.72 billion in 2004 (Tourism Malaysia, 2005).

Song and Witt (2000) described tourism demand as the amount of a set of tourist products that the consumers are willing to acquire during a specific period of time and under certain conditions which are controlled by the explanatory factors used in the demand equation. Smeral (1988) and Syriopoulos and Sinclair (1993) empirically examined the relationships between the variables underlying the determinants of tourism demand. Few econometrics models have also been developed in identifying the relationship between tourist arrivals in a particular country and the factors that influence the arrivals. Lim (1997), Song and Witt (2000) and Song et al., (2003) contended that econometric forecasting models have the advantage of demonstrating the extent to which forecasts changed as a result of changes in the variables that act as economic drivers of tourism. In addition, most of the previous studies have also used the demand function approach to identify the quantitative relationships of tourism demand (Loeb, 1982; Nordström, 1996; Uysal and Crompton, 1982). Despite the proliferation of those studies, little focus have been given on the statistical properties of an important time series, namely on the international tourist demand (Jorgensen, 1996; Muller, 1999).

Having succinctly introduced the issue, this paper is estimating tourism demand in Malaysia based on the key economic factors like income, price, exchange rate, 
consumer price index, distance, population and economic crisis using a modified Gravity model. In addition, the movement, pattern and changes of international tourist arrivals are also examined.

\section{Methodology}

Before proceeding into the methodology used, it is important first to explain the Gravity Model used by Tinbergen (1962). He claimed that the gravity models utilized the gravitational force concept as an analogy to explain the volume of trade, capital flows, and migration of people among the countries in the world. Tinbergen (1962) also proposed that the same functional form of the model could be applied to estimate the international migration flows In many instances, gravity models have a significant explanatory power which Deardorff (1998) refers as a "fact of life." Despite some ambiguity, the gravity model used by Tinbergen (1962) is considered the most appropriate empirical tool to understand trade and other economic flows in the world of economy. His general gravity law for social interaction is expressed in this notation:

$$
F_{i j}=\underset{d_{i j}{ }^{\theta}}{G} \underline{m}_{i}^{\alpha} \underline{m}_{i}^{\beta}
$$

where notation is defined as follows:-

- $\boldsymbol{F}_{\boldsymbol{i} j}$ is the "flow" from origin $\boldsymbol{i}$ to destination $\boldsymbol{j}$. Alternatively, it represents total volume of interactions between $i$ and $j$ (i.e. the sum of the flows in both directions)

- $\boldsymbol{M}_{\boldsymbol{i}}$ and $\boldsymbol{M}_{\boldsymbol{j}}$ are the relevant economic sizes of the two locations.

- If $\boldsymbol{F}$ is measured as a monetary flow (e.g. export values), then $\boldsymbol{M}$ is usually the gross domestic product (GDP) or gross national income (GNI, formerly GNP) of each location.

- For flows of people, it is more natural to measure $\boldsymbol{M}$ with the populations.

- $\boldsymbol{D}_{i j}$ is the distance between the locations (usually measured center to center) - distance between 2 different places or countries.

Rodrigue (2004) used the Tinbergen Gravity Model for the purpose of estimating tourism demand. A slight adjustment has been made by converting the variables proposed by Tinbergen (1962) to suit the tourism related variables. The tourism demand estimation modified by Rodrigue's are as follows:

$$
T D_{i j}=\underset{d_{i j}^{2}}{k} \underline{m}_{i} \underline{m}_{i}
$$

where :

$\boldsymbol{T D}_{i j}$ is the total tourist arrival from country $\mathrm{i}$ and visiting Malaysia, $\mathrm{j}$.

$\boldsymbol{k}$ is constant

$\boldsymbol{m}_{\boldsymbol{i}}$ is measured as a factor to generate movement of international tourism

$\boldsymbol{m}_{j}$ is measured as a factor to attract movement of international tourism

$\boldsymbol{d}_{i j}$ is the distance between the origin country and Malaysia

In line with the above notion, this study adopted Rodrigue (2004) modified Gravity model to estimate tourist movement and pattern of international tourist to Malaysia. The tourism demand was depending on the Gross National Income per capita of tourist's origin country, Consumer Price Index (CPI) ratio of Malaysia over origin country, CPI of Malaysia, Population, Distance and Malaysia's exchange rate differences and economic crisis in 1997.

However, Lim (1997) indicated that nearly $80 \%$ of empirical studies on tourism demand or arrivals used single equation of linear and/or log linear equation because the estimated coefficients can be interpreted as elasticities. Therefore, the variables such as $\log$ (GNIim), $\log$ (CPIim), $\log$ (CPImas), $\log$ (ERim), $\log$ (DISim) and $\log$ (POPim) are treated as endogenous variables while (ECim) is entered as exogenous variables in this study. The log-linear model based on the Gravity Model for this present study is as follows:-

$$
\begin{array}{r}
\log \left(\mathrm{TA}_{\text {im }}\right)=\dot{\alpha}+\beta_{1} \log \left(G N I_{\text {im }}\right)+\beta_{2} \log \left(C P I_{i m}\right) \\
+\beta_{3} \log \left(C P I_{\text {mas }}\right)+\beta_{4} \log \left(E R_{i m}\right)+\beta_{5} \log \left(P O P_{i m}\right)+ \\
\beta_{6}\left(D I S_{i m}\right)+\beta_{7}\left(E C_{i m}\right)+u_{i}
\end{array}
$$

where

$\boldsymbol{\alpha}$ is constant

$\boldsymbol{T} \boldsymbol{A}_{\boldsymbol{i m}}$ is the number of tourist arrivals in Malaysia

$\boldsymbol{G N I}_{\boldsymbol{i m}}$ is the gross national income

$\boldsymbol{C P I _ { i m }}$ is the consumer price index

$\boldsymbol{E R}_{\boldsymbol{i m}}$ is the exchange rate

$\boldsymbol{P O P}_{\text {im }}$ is the population

$\boldsymbol{D} I \boldsymbol{S}_{\boldsymbol{i m}}$ is the distance

$\boldsymbol{E C}_{\boldsymbol{i m}}$ is the economic crisis

where the sub index $\mathrm{i}$ is for origin country, $\mathrm{m}$ is for Malaysia and $\log$ denotes the natural logarithms.

The available data from unpublished Tourism Malaysia report from the year 1993 till 2007 was used to estimate the movement of the tourist arrivals relating to the key economic factors. 7 independent variables; consisting 6 explanatory variables and 1 dummy variable is used for this purposed. The data on arrivals of the international tourists from 7 countries namely Australia, Hong Kong, Indonesia, United Kingdom, Thailand, Taiwan and China was used in this study due to the unavailability of data from other countries. Data was gathered with the permission of Tourism Malaysia. The data was analyzed using e-Views version 4.0.

\section{RESUltS AND DisCUSSION}

\section{A. Model Result}

To estimate tourist arrivals and patterns, multiple regression techniques on a pooled time-series cross-sectional was undertaken based on the gravity model.

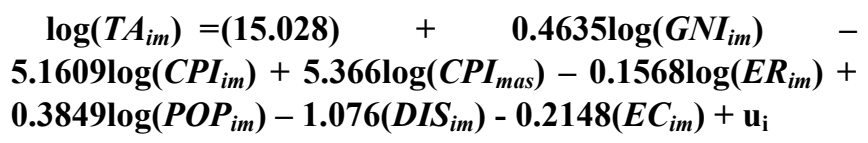

R-squared : 0.595745, Adj. R-squared : 0.558511

Durbin Watson : $0.674692, \boldsymbol{n} \boldsymbol{R}^{2}=\chi^{2}: 50.04258$

The adjusted $\mathrm{R}$-squared value was around 0.5585 , which shows no Multicollinearity problem. To prove it, a 
calculation of Variance-Inflation-Factors (VIF) for the TAim has been done. There is supporting evidence that TAim is absence of Multicollinearity as the value is less than 4 (rule of thumb) (Gujarati, 1998)). The serial correlation is positive as shown by the Durbin Watson statistic, which is around the value of 0.6746 indicated that there is positive (first-order) serial correlation in the tourism demand regression residuals.

\section{B. Model Justification}

A series of t-test at $1 \%$ and $5 \%$ significant level have been applied on each independent variable against the dependent variable. From the above gravity model equation, (GNIim), (CPIim), (CPImas), (DISim), (POPim) share the same significant level of $5 \%$.(ERim) and (ECim) is significant at $1 \%$. Overall, all independent variables are significant towards the dependent variable and it shows that there are significant relationships between these variables. In other words, there are relationships between tourism demand with price, income, distance, population and economic crisis.

In order to determine whether there are significant relationships between the independent variables (price, income, distance, population and economic crisis) as a group and the dependent variable (tourism demand), F-test was used as recommended by Brakke (2004) .

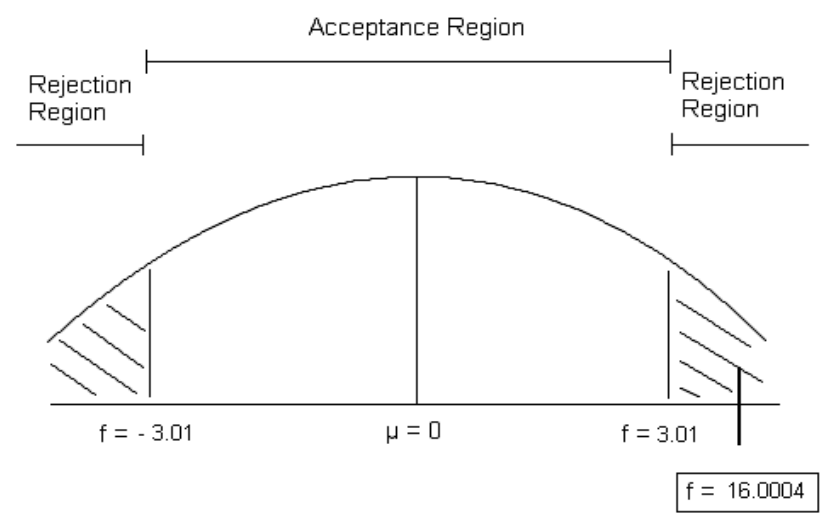

As indicated, F-value (16.0004) is more than critical F-distribution value; implying that one can reject the null hypothesis and concludes with $95 \%$ confidence interval that the independent variables as a whole explained a significant changes in tourism demand. In the simple term, it can be said that price, income, distance, population and economic crisis as a group have given significant effect either positive or negative towards tourism demand.

\section{Variables Significant}

On the income, result showed that $1 \%$ increase in GNI per capita of the origin countries, it would increase $0.463 \%$ tourist arrivals to Malaysia. GNI per capita had been described as the best indicators on level of economics development and its positive coefficient correspond with the purchasing power and spending ability (Jensen, 1998; Kulendran and Wilson, 2000). On price, $1 \%$ increase in the Consumer Price Index ratio would decrease 5.16\% tourist arrivals in Malaysia. Inline with that, the CPI can be described as the pulling factor in attracting tourist to visit Malaysia as it offers a lower cost of living, cheaper food, accommodation and transportation cost. The CPI rate of
Malaysia is also used as a variable to test the inflation rate effect towards tourism industry. Result revealed that an increase of $1 \%$ in CPI of Malaysia has contributed to the increase in the number of tourists' arrival in Malaysia by $5.366 \%$. From this result, it could be assumed that there will be high value in CPI in any developing country like Malaysia where the government will spend more money on the development for better living condition and encourage tourism in the country.

The third analysis was looking at the variable of population. An increase of $1 \%$ of population of the origin country would generate $0.384 \%$ increased in tourist arrivals in Malaysia. The world population is getting bigger and bigger over the time and it clearly shows that all tourism multipliers are positively correlated with the natural log of population except for job multipliers, which are negatively correlated. With regard to the exchange rate, an increase of $1 \%$ in exchange rate of Malaysia would decrease $0.156 \%$ tourist arrival in Malaysia. The effect of devaluation in the exchange rate indices can be both positive and negative depending whether the value of exchange rate of origin country has relatively increased or decreased. Prideaux and Witt (1999a) examined tourist flows between ASEAN countries and Australia found that outbound tourism from Australia increased in response to a fall in the value of many Asian currencies relative to the Australian dollar.

An increase of $1 \%$ in distance between the tourist's origin country and Malaysia would reduce the tourist arrivals by $1.075 \%$ proving that the fares or transportation cost is higher as the distance is greater. Hummels (1999) and Krugman (1991) proved that distance showed the cost of transportation and can be used as a substitute of cost of traveling imposed to the potential tourist is higher for long distance traveling.It can be interpreted that during the economic crisis in South East Asia, the numbers of tourist arrival to Malaysia reduced to $17.75 \%$ or showing a negative relationship of the tourist movement. Prideaux and Kim (1999) claimed that tourist from ASEAN countries that were affected by economic crisis will cut down their tourism expenditure to control the loss from their own currency cut down but generate demand from the western continents to visit the ASEAN countries.

\section{CONCLUSION}

This paper applied Rodrigue (2004) modified Gravity model to estimate tourist movement and pattern of international tourist to Malaysia.Our main finding can be summarized as follows.From the tested model (Gravity model) used in this study, a few conclusion could be made. Firstly, there are strong relationship between the key economic factors and decision to travel among the tourists. Secondly, the high gross national income, lower inflation, high population rates and short haul destination influenced tourist to visit Malaysia. Thirdly, economic crisis negatively affected the tourism demand from the ASEAN countries but positively correlated with the western and other continents. In other word, despite the economic turmoil, the international tourist arrivals to Malaysia particularly from western and other continent have increased. In sum, despite of regional economic crisis, Malaysian government can still rely on 
tourism industry as a means for sustaining the economy. To strengthen this result, a similar study should be replicated using a bigger sample and current data.

\section{REFERENCES}

[1] Andersson, T. (1998). An alternative model of economics impact analysis, using dividends instead of multiplier (working paper). European Tourism Research Centre Sweden.

[2] Crouch, G.I. (1994). The study of international tourism demand: A review of findings. Journal of Travel Research 44, 12-23.

[3] Engle, R.F. and Granger, C.W.J. (1987). Co integration and error correction: Representation, estimation and testing. Econometrica 55, 251-76.

[4] Eilat, Y., Einav, L. (2004). "Determinants of international tourism: a three-dimensional panel data analysis", Applied Economics, 36, 1315-1327.

[5] Fizari, F. (2006). An Application of Gravity Model in Education Tourism: A Case of IIUM Undergraduate Admissions. Malaya University Postgraduate Research

[6] Fuller, W. (1976). Introduction to Statistical Time Series. New York: John Wiley.

[7] Gary, H.P. (1996). 'The demand for international travel by the United States and Canada', International Economic Review, 7 (1), 83-92.

[8] Khalik, A.S. (1998). Estimating Tourist Demand through Co integration Analysis: Swedish Data. Mid Sweden University, Östersund.

[9] Kulendran, N. (1996). Modeling quarterly tourist flow to Australia using co integration analysis. Tourism Economics 2 (3), 203-22.

[10] Lim, C. (1997). "Review of International Tourism Demand Models", Annals of Tourism Research, 24 (4), 835-849.

[11] Loeb, P. D. (1982). "International Travel to the United States: An Econometric Evaluation", Annals of Tourism Research, 9 (1), 7-20.

[12] Morley, C.L. (1998). "A Dynamic International Demand Model", Annals of Tourism Research, 25 (1), 71-84.

[13] Song, H., Witt, S.F., (2003)," Tourism Forecasting: The General-To-Specific Approach", Journal Of Travel Research, 42, 65-74.

[14] Smeral, E. (1988). Tourism demand, economic theory and econometrics: An integrated approach. Journal of Travel Research, $38-43$.

[15] Uysal, M. and Crompton, J.L. (1982). Determinants of demand for international tourist flow to Turkey. Tourism Management 12, 288-97.

[16] World Tourism Organisation (2002) Tourism Highlight 2002, Madrid: World Tourism Organisation

[17] World Travel \& Tourism Council (2006) press release 2006 (http://www.wttc.org/eng/Tourism_News/Press_Releases/Press_Relea ses_2006) 